\title{
Islams komplethed (šumuliyyat al-Islam), kontinuitet eller brud?
}

\author{
Ahmed Abou El Zalaf
}

\begin{abstract}
Foreliggende artikel havder, at Hasan al-Banna (d. 1949) formulerede en politisk-islamisk ideologi, der blev anvendt som ramme for Det Muslimske Broderskabs mobilisering og udbredelse i det egyptiske samfund. Bevagelsen fortolkede islam som et komplet system og en livsfilosofi (šumuliyyat al-islam), der if $\phi$ lge bevagelsens strategi skulle udgфre fundamentet for reform $i$ Egypten såvel som $i$ resten af den islamiske verden. Denne artikel vil diskutere, hvorvidt šumuliyyat al-islam (islams komplethed) reprasenterede et brud med det traditionelle islam, eller om denne ideologi i grunden udgjorde en fortsattelse af en lang tradition, hvor islam har varet anskuet som et holistisk system. Dertil vil artiklen undersøge, hvordan ovenstående ideologi, blev italesat $i$ en moderne kontekst. I den forbindelse vil artiklen demonstrere, hvilke koncepter Det Muslimske Broderskab adopterede fra de vestlige ideologier, og hvordan disse koncepter blev italesat som traditionelle islamiske koncepter for at fremhjalpe Broderskabets mobilisering $i$ samfundet.
\end{abstract}

"i vores forståelse udgør islam et komplet system (šumuliyyat alislam), som organiserer alle livets aspekter og prædiker $\mathrm{i}$ alle sammenhænge og grundlægger et præcist styresystem (for det islamiske samfund). [...] nogle mennesker tror ved en fejl, at islam er begrænset til tilbedelse og spirituelle aspekter af livet. [...] Vi (det Muslimske Broderskab, red.) forstår dog islam som et system, der organiserer både dette liv og det næste ${ }^{1}$. Denne opfattelse stammer fra Koranen og den islamiske tradition"2 Hasan al-Banna ${ }^{3}$.

Siden 1940'erne har det Muslimske Broderskab udgjort den mest dominerende og magtfulde politisk-islamiske socialbevægelse i Egypten såvel som i store dele af Mellemøsten. Bevægelsen blev grundlagt i 1928 som en lokal reformbevægelse begrænset til

\footnotetext{
${ }^{1}$ Med det næste hentyder al-Banna til de religiøse aspekter af samfundets forhold. Derved gøres det gældende, at det Muslimske Broderskabs diskurs berører verdslige forhold som statens opbygning såvel som sakrale forhold i samfundet.

${ }^{2}$ Citatet er oversat fra Arabisk af undertegnede

${ }^{3}$ Al-Banna, 2004, side 18.
} 
kanalzonebyen al-Isma'iliyya. I løbet af 1930'erne og især efter 1936 formåede det Muslimske Broderskab at udføre en radikal ekspansion, og gennem en exceptionel mobiliseringsevne overgik bevægelsen alle andre politiske aktører i det egyptiske samfund. Størstedelen af undersøgelserne omhandlende det Muslimske Broderskab har fokuseret på bevægelsens politiske ageren i forbindelse med forskningen i "Islamic Resurgence"4. Der synes dog at være en ganske bestemt side af det Muslimske Broderskabs udvikling og diskurs, der indtil videre er blevet fejlfortolket $\mathrm{i}$ dele af den foreliggende vestlige forskning. Der forekommer i den eksisterende forskning en antagelse af, at det Muslimske Broderskabs politisk-islamiske ideologi udelukkende repræsenterede et brud med det traditionelle islam. Vestlige forskere har gennem flere perioder diskuteret konceptet "islams komplethed" (šumuliyyat al-islam), som udgjorde kernepunktet hos Broderskabet. Flere af disse værker har, som vi skal se, anskuet dette koncept som et innovativt fænomen udarbejdet af moderne islamistiske bevægelser, hvor det var gavnligt for deres agendaer. Nærværende artikel $\emptyset$ nsker at redegøre for indholdet af Hasan al-Bannas (d.1949) ${ }^{5}$ koncept šumuliyyat al-islam(islams komplethed) for derved at diskutere, hvorvidt hele dette koncept repræsenterede et brud med den traditionelle islam, eller om Hasan alBanna udarbejdede en syntese mellem en traditionel islamisk ideologi og moderne vestlige koncepter. Artiklen vil dertil diskutere denne ideologis betydning for det Muslimske Broderskabs mobilisering i perioden 1928-1941.

\section{Et intellektuelt brud}

Det Muslimske Broderskab opstod i en periode, hvor der forekom en udbredt identitetskrise i det egyptiske samfund. Egypten stødte i forbindelse med Napoleons felttog (1798-1801) på vestlige kulturelle og politiske idéer, som hidtil havde været fremmede for de islamiske samfund ${ }^{6}$. Mødet med, og overdragelsen af, vestlige idéer opstod i forbindelse med Mohammad Alis kontakt til den vestlige verden og steg derefter i takt med udbredelsen af den vestlige kolonialisme i regionen. Den britiske kolonisering af Egypten i 1882 medvirkede i vid udstrækning til dannelsen af en identitetskrise, som især prægede den intellektuelle klasse i samfundet. Denne krise kom i overvejende grad til udtryk gennem et intellektuelt brud og en polemik omkring, hvordan Egypten kunne imødekomme modernitetens udfordringer.

\footnotetext{
${ }^{4}$ Guirguis, Max 2012, side 187.

${ }^{5}$ Hasan al-Banna (1906-1949) født i Buhayra-provinsen i byen Mahmudiyya, omkring $145 \mathrm{~km}$ nordvest for Cairo. Al-Banna var uddannet skolelærer, men var samtidig lærd indenfor de religiøse traditioner. Al-Banna grundlagde gennem sin ungdom flere reform bevægelser inden han i 1928 grundlagde det Muslimske Broderskab i kanalzonebyen al-Isma'iliyya.

${ }^{6}$ W. Said, Edward, 2015, side 152.
} 
Den egyptiske forsker Ibrahim al-Bayyumi Ghanem gør i denne forbindelse gældende, at kulturmødet med Vesten kom i en periode, hvor de muslimske samfund stod svagt vis-a-vis de vestlige magter, og derfor fik Vestens idéer og begreber overhånd især blandt den intellektuelle litterære befolkningsgruppe ${ }^{7}$. Den svage tilstand, som de islamiske områder var præget af, gav anledning til fremkomsten af forskellige reformidéer som italesatte divergerende bud på, hvordan den islamiske verden kunne gennemgå en renæssance og overkomme svagheden og tilbageståenheden, som prægede deres samfund.

Det var i denne forbindelse, at den islamiske reformbevægelse "Salafiyyabevagelsen" opstod og formulerede forskellige koncepter til afhjælpningen af de islamiske samfunds svækkelse. Tænkere som Muhammad Abduh (d.1905) og Muhammad Rašid Rida (d.1935) udarbejdede forskellige islamiske såvel som sociale reformkoncepter til afhjælpningen af ovenstående forhold. Disse idéer er vigtige, idet de sidenhen har opnået dominerende indflydelse på den islamiske reformtænkning og især Det Muslimske Broderskabs begrebsverden. Blandt de koncepter, som fik størst indflydelse på de moderne islamistiske bevægelser, var koncepterne panarabisme, panislamisme samt antiimperialisme ${ }^{8}$. Koncepterne panislamisme og panarabisme, som går igen blandt flere af reformtænkerne i slutningen af det 19.århundede og igennem det 20.århundede, bliver i høj grad, i forskningen, sporet tilbage til reformtænkeren Jamal al-Din al-Afghani(d.1897). Afghani italesatte dette koncept som reaktion på den vestlige kolonisering af store dele af den islamiske verden ${ }^{9}$.

Influeret af disse idéer, anførte Hasan al-Banna, gennem Broderskabets organer, at reformen $\mathrm{i}$ den islamiske verden skulle baseres på panislamisk og panarabisk solidaritet. Broderskabet var af den anskuelse, at konfronteringen af den vestlige dominans i regionen, kun kunne udføres gennem de ovenstående koncepter. Broderskabet og salafiyya-tænkerne var ligeledes enige om, at udviklingen i den islamiske verden kun kunne opnås, såfremt muslimerne vendte tilbage til "islams rene kilder"10. Denne anskuelse var baseret på forestillingen om, at svagheden i de islamiske samfund et langt stykke hen ad vejen beroede på muslimernes afvigelse fra den oprindelige islam.

Der forekom imidlertid i samme periode en divergerende fløj, som anså indtoget af vestlige idéer i regionen radikalt anderledes. Den sekulære egyptiske elite gjorde i modsætning til den islamiske lejr gældende, at løsningen på de islamiske samfunds forfald i vid

\footnotetext{
7 Al-Bayyumi Ghanem, Ibrahim, 2013, side 66.

${ }^{8}$ R. Keddie, Nikki, 2008, side 19.

${ }^{9}$ R. Keddie, Nikk, 2008, side 19.

${ }^{10}$ Med Islams rene kilder menes Koranen og Profeten Muhammads Sunna (sædvane). Ifølge disse tænkere skulle man adskille mellem samtidens islam og det oprindelige islam, som repræsenterede det sande islam fra Profetens og hans øjeblikkelige efterfølgeres tid. Se fx Rahmena, Ali, 2008, side xli.
} 
udstrækning bestod af, at man imiterede Vesten for derved at opnå samme grad af udvikling, som var kendt fra Vesten. Denne opfattelse demonstrerer et klart brud med den førnævnte islamiske diskurs ${ }^{11}$, som ikke undervurderede modernismen i den vestlige verden, men anskuede, at muslimerne ville opnå samme grad af modernisering, hvis de vendte tilbage til de tidlige islamiske koncepter ${ }^{12}$. Den sekulære, vestligt orienterede lejr, hævdede dertil, at renæssancen i de islamiske samfund kun kunne virkeliggøres, såfremt det egyptiske samfund imiterede vestens moderne institutioner samt indarbejdede vestlige kulturelle, sociale og politiske begreber i Egyptens statssystem. ${ }^{13}$. Salama Musa (1887-1958) ${ }^{14}$ hævdede i 1928, at Egypten skulle "instituere en fuldstoendig toet forbindelse til Europa... $v i$ (egypterne eller den egyptiske elite, red.) skal forstå verden på samme måde, som Europa gør det", Salama postulerede dertil, at " italesattelsen af en affinitet med Østen (den arabiske og islamiske verden, red.) er tåbelig, idet der ikke findes ligheder mellem Egypten og Østen" ${ }^{\prime 2}$. Den egyptiske forfatter Taha Hussein skrev i sit værk" The Future of Culture in Egypt", at det egyptiske samfund i stigende grad rykkede tættere på Europa kulturelt og var i gang med at opstå som en central del af Europa ${ }^{16}$.

Dette intellektuelle og diskursive brud, som prægede den egyptiske offentlighed i perioden efter den britiske kolonisering af landet, resulterede $\mathrm{i}$ en identitetskrise og medvirkede til dannelsen af Det Muslimske Broderskab i 1928. Artiklen vil nedenfor illustrere Hasan al-Bannas idémæssige respons til den udbredte vestliggørelse og sociale krise, som prægede samfundet, for derved at fremhæve, hvordan idéen om islams komplethed blev italesat gennem moderne begreber og aktiviteter.

\section{Islams komplethed (Šumuliyyat al-Islam)}

\section{Det Muslimske Broderskabs opståen}

Som nævnt ovenfor dannede det intellektuelle brud bevæggrund for grundlæggelsen af Det Muslimske Broderskab. Mellemøstforskeren Khalil al-Anani påpeger, at Broderskabets tilblivelse udgjorde en reaktion

\footnotetext{
${ }^{11}$ Al-Bayyumi, side 68.

${ }^{12}$ Haddad, Yvonne, 2008, side 43.

${ }^{13}$ al-Anani, Khalil " The Power of the Jama 'A: The Role of Hasan Al-Banna in Constructing the Muslim Brotherhood's Collective Identity" fra "Sociology of Islam. S, 41-63. Side 44.

${ }^{14}$ Salama Musa var en betydningsfuld egyptisk journalist og reformator, med en sekulær vestlig tilgang. Han rejste til Europa i 1908, hvor han studerede filosofi, litteratur, samfundsvidenskab og naturvidenskab. Han var stærkt kritisk overfor sine konservative modstandere.

${ }^{15}$ Al-Bayyumi, side 91.

${ }^{16}$ J. Donohue, John \& L. Esposito, John, 2007, side 57.
} 
på identitetskrisen og bruddet, som kendetegnede det egyptiske samfund. Ifølge al-Anani var det essentielt for Hasan al-Banna at etablere en identitetsbevægelse, som kunne rumme islamiske værdier og idealer i hverdagslivet, for derved at modarbejde udbredelsen af vestlige idéer og normer i det egyptiske samfund ${ }^{17}$. Denne fremstilling stemmer overens med Hasan al-Bannas beretning, idet han tilkendegav, at han i sin tid i Kairo $^{18}$ stødte på:

"En bølge af opløsning, som underminerede alle faste overbevisninger samt opslugte Egypten under påskud af den "intellektuelle frigørelse". Denne tendens angreb moral, gode gerninger og dyder under påskud af personlig frihed. Intet kunne stå imod denne kraftfulde og tyranniske strøm af vantro og eftergivenhed, der fejede over vores land, hjulpet frem af begivenhederne og omstændighederne"19.

Hasan al-Banna gjorde ligeledes gældende, at bølgen af vestlige idéer og principper, som i denne periode udbredte sig i det egyptiske samfund, appellerede til "de intellektuelle unge[...]"20. Af denne grund anslog alBanna, at det var nødvendigt at etablere en islamisk respons til denne:

"Vestlige invasion, som er bevæbnet med destruktive våben i form af penge, velstand, prestige, opvisning og styrke samt midlerne til propaganda" 21 .

Egypten vidnede dertil igennem 1930'erne fremkomsten af den økonomiske verdenskrise, som påvirkede en bred sektor af den egyptiske befolkning ${ }^{22}$. I forlængelse af krisen blev de sekulære liberale kræfter diskrediteret i samfundet, ikke mindst fordi disse kræfter mislykkedes i at udarbejde konkrete reformidéer som modsvar til krisen ${ }^{23}$. Det lykkedes imidlertid Hasan al-Banna på vegne af Det Muslimske Broderskab at italesætte klare reformidéer (islah) til hæren, uddannelsessektoren, industrien og økonomien, der alle skulle gennemføres gennem et skift fra det "korrupte system, man har imiteret fra Vesten, til et islamisk system baseret på Guds lov i alle samfundets sfarer" ${ }^{24}$. Al-Banna fastholdt i sine tekster og taler, at renæssancen (nahda) og reformen (islah) i det egyptiske samfund alene kunne opnås, hvis hele samfundet efterlevede retningslinjerne fra Koranen og profetens sædvane (sunna $)^{25}$. Al-Banna fremhævede

\footnotetext{
${ }^{17}$ Al-Anani, side 46.

${ }_{18}$ Al-Banna studerede i Kairo i perioden 1923-1927.

${ }^{19}$ Al-Banna "Mudhakirat al-Da'wa..." side 65.

${ }^{20}$ Ibid., Side 67.

${ }^{21}$ Ibid., Side 67.

${ }^{22}$ Geroshni Israel, \& P. Jankowski James, 2002, side 2.

${ }^{23}$ Abd al-Halim, Mahmoud, 1994, side 134.

${ }^{24}$ Al-Bayyumi, side 313.

${ }_{25}$ Al-Banna 2004, side 93.
} 
bl.a. i et åbent brev" Mellem $i$ dag og i Går (bayna al-yawm walams)", at Koranen og profetens traditioner omfatter de nødvendige reformidéer til den islamiske verden ${ }^{26}$. Han gjorde i samme brev gældende, at muslimernes afvigelse fra islam, som et dogme ('aqida) og praktiske handlinger ('amal) førte til muslimernes dekadence og svaghed og som følge af dette "kalifatets fald $i$ 1924"27. Al-Banna tydeliggjorde, at den "islamiske reform" blandt andet skulle omfatte loven og den økonomiske sfærer. Han fastholdt, at loven skulle reformeres, så den opnåede den fornødne islamiske karakter. Vigtigst ifølge al-Banna var, at disse reformidéer skulle udarbejdes som substantielle reformaktiviteter i samfundet. Han understregede, at taler og seminarer ikke alene kunne virkeliggøre den intenderede reform ${ }^{28}$. Som det vil fremgå af denne artikel, forekommer der en utilstrækkelighed i al-Bannas skildring af bevægelsens ideologi, som udelukkende islamisk. Ideologien hos Det Muslimske Broderskab byggede i høj grad på islamiske koncepter, som fx bevægelsens agitation for at udarbejde en islamisk reform i samfundet, det fremgår imidlertid, at bevægelsen ligeledes inkorporerede moderne koncepter som nationalisme socialisme i deres ideologi. Disse koncepter blev dog italesat som traditionelle islamiske koncepter, formentlig i et forsøg, fra bevægelsens side, på at opretholde en islamisk diskurs som skulle karakterisere alle bevægelsens aspekter.

Det Muslimske Broderskab grundlagde i forlængelse af den ovennævnte socioøkonomiske krise et komplekst netværk af sociale og økonomiske institutioner, som fremhjalp bevægelsens evne til at eksekvere reformen i samfundet. Kamal al-Helbawy anfører, at Broderskabet i den formative periode ${ }^{29}$ etablerede omkring 2000 velgørende sociale institutioner ${ }^{30}$. Al-Banna bekendtgjorde $\mathrm{i}$ et åbent brev fra 1934 " $E r$ vi praktiske folk? (Hal nahnu qawmun 'Amaliyyun?)', at Det Muslimske Broderskab havde spredt sig til 50 egyptiske byer, og i alle byerne havde bevægelsen etableret "gavnlige" institutioner ${ }^{31}$. Al-Banna specificerede, at man i disse byer havde etableret moskeer, sociale klubber og uddannelsesinstitutioner. Bevægelsen stiftede endvidere $\emptyset$ konomiske virksomheder, som skabte arbejdspladser for de dårligt stillede i lokalsamfundene ${ }^{32}$. Disse etablissementer repræsenterede et vigtigt aktiv for Broderskabet, idet bevægelsen gennem sådanne institutioner

\footnotetext{
${ }^{26}$ Al-Banna, 2004, side 93-95.

${ }^{27}$ Ibid., side 96-97.

${ }^{28}$ Ibid., side 106-108.

${ }^{29}$ Det Muslimske Broderskabs formative periode strakte sig i perioden 19281941, i den periode formulerede bevægelsen en stor del af sine koncepter og idéer. Det var endvidere i den periode, at bevægelsen opbyggede sin organisatoriske struktur.

${ }^{30}$ Helbawy, Kamal, 2010, side 74.

${ }^{31}$ Al-Banna " Brevsamlingen (Majmu'at al-Rasail..)", side 64.

${ }^{32}$ Ibid., Side 64.
} 
evnede at omdanne deres reformidéer til praktiske og substantielle aktiviteter blandt masserne.

\section{Broderskabets islamiske diskurs}

Der forekommer i tekster skrevet af ledere fra Det Muslimske Broderskab en omfattende beskrivelse af bevægelsens forståelse af islam. Bevægelsens ideologer har i vid udstrækning understreget, at deres anskuelse af islam som et omfattende system, er i overensstemmelse med den sande islamiske tradition, som står skrevet i de normative tekster (Koranen og profetens traditioner "Hadith"). Hasan al-Banna karakteriserede Broderskabets forståelse af islam som følgende:

"i vores forståelse udgør islam et komplet system (ك̌umuliyyat al-islam), som organiserer alle livets aspekter og prædiker i alle sammenhænge og grundlægger et præcist styresystem (for det islamiske samfund). [...] nogle mennesker tror ved en fejl, at islam er begrænset til tilbedelse og spirituelle aspekter af livet. [...] Vi (Det Muslimske Broderskab, red.) forstår dog islam som et system, der organiserer både dette liv og det næste ${ }^{33}$. Denne opfattelse stammer fra Koranen og den islamiske tradition" ${ }^{34}$.

Islam repræsenterede ifølge al-Banna en social såvel som en religiøs og politisk ideologi, der ikke måtte degraderes til blot at omhandle tilbedelse og religiøse aspekter ${ }^{35}$. Al-Banna tilføjede dertil, at islam i sit sande format består af:

"tro og tilbedelse, nation og nationalitet, moral og materialisme, nåde og styrke og kultur og lov, tro og stat, regering og samfund, Koran og sværd [...] "36.

Sa'id Hawwa, en prominent ideolog fra Det Muslimske Broderskab, har i sit værk "Al-madkhal ila da'wat al-ikhwan al-muslimiin (indgangen til Det Muslimske Broderskabs mission)" beskrevet den sociale og kulturelle kontekst, hvori Broderskabet opstod. Hawwa skrev bl.a., at muslimerne i perioden frem til grundlæggelsen af Det Muslimske Broderskab i 1928 havde glemt idéen om, at islam udgjorde et omfattende system for hele eksistensen. Han tilføjede endvidere, at islam var blevet degraderet som følge af det voldsomme

\footnotetext{
${ }^{33}$ Med det næste hentyder al-Banna til de religiøse aspekter af samfundets forhold. Derved gøres det gældende, at det Muslimske Broderskabs diskurs berører verdslige forhold som statens opbygning såvel som sakrale forhold i samfundet.

${ }^{34}$ Al-Banna " Brevsamlingen (Majmu'at al-Rasail..)"side 18.

${ }^{35}$ Al-Banna " Brevsamlingen (Majmu'at al-Rasail..)" side 152.

${ }^{36}$ Al-Banna " Brevsamlingen (Majmu'at al-Rasail..)"side 202.
} 
angreb, den var udsat for. Ifølge Sa'id Hawwa lykkedes det Hasan alBanna at gen-italesætte forståelsen af islam som et komplet system, der definerer alle livets aspekter ${ }^{37}$. Sa'id Hawwa opfattede konceptet, islams komplethed som et traditionelt aspekt repræsenterende en central del af den islamiske tradition. Han skrev blandt andet i denne forbindelse, at "islam blev åbenbaret som en religiøs platform (minhaj), og gennem denne platform blev livets aspekter systematiseret" 38 .

Som det vil fremgå af det nedenstående afsnit, opfattede dele af den vestlige forskning syntesen mellem religion og politik som en innovativ opfindelse, udarbejdet af de moderne islamistiske bevægelser, i forsøget på at gavne bevægelsernes interesser. Dette er relevant, idet der følgelig forekommer en klar divergens mellem på den ene side dele af den vestlige opfattelse og på den anden de islamistiske bevægelsers selvopfattelse. Det er imidlertid væsentligt, at understrege $\mathrm{i}$ denne forbindelse, at der i den vestlige forskning eksisterer en anden forskningsfløj, som ikke lider af samme bias. Den ovenstående anskuelse af šumuliyyat al-islam, som et innovativt fænomen, karakteriserede særligt forskningen i perioden 1950-1980. Denne tendens i forskningen beroede i høj grad på modernitetsteorien, som karakteriserede islamforskningen i den førnævnte periode. Der forekommer dog i den vestlige forskning en divergerende fløj, der skildrer šumuliyyat al-islam, som et traditionelt og velkendt koncept, der går tilbage til profetens tid i det syvende århundrede. J. Donohue og L. Esposito gjorde fx gældende, at den muslimske selvforståelse er baseret på Koranen og den tidlige gloværdige islamiske periode, hvor islam blev opfattet som et holistisk system, der sammenflettede religion med politik, lov og samfund ${ }^{39}$. Peter Mansfield var af samme overbevisning. Han gør således gældende, at islam, efter profetens migration til Medina i 622, begyndte at udvikle sig til et "politisk organiseret samfund, såvel som en religion" $"$.

\section{Politisk Islam, innovation kontra tradition.}

\section{Den vestlige opfattelse}

Dele af den vestlige forskning har fortolket syntesen mellem politik og islam ${ }^{41}$ som et innovativt fænomen, der blev sat sammen af moderne islamistiske bevægelser for at tjene bevægelsernes politiske interesser. Forskerne har dertil anskuet denne syntese som et tegn på

\footnotetext{
${ }^{37}$ Hawwa, Sa'id, 1984, side 35.

${ }^{38}$ Ibid., side 68.

${ }^{39}$ J. Donohue \& L. Esposito, 2007, side 2

${ }^{40}$ Mansfield, 1992, side 23.

${ }^{41}$ Islam og politik udgjorde de to fundamenter i det Muslimske Broderskabs ideologi. Ifølge Hasan al-Banna var disse to sider uadskillelige.
} 
de islamistiske bevægelsers fejlslagne forsøg på at italesætte en ideologi i overensstemmelse med den moderne tid. Forskeren Nadav Safran opfattede Det Muslimske Broderskabs islamiske diskurs som en indikation på, at bevægelsen ikke havde været $i$ stand til at udarbejde en moderne ideologi. Modsat de sekulære bevægelser magtede Broderskabet kun at italesatte et "dogme" baseret på tro frem for systematisk tænkning ${ }^{42}$. I forlængelse af det ovennævnte anskuede han Broderskabets religiøse diskurs samt mangel på et moderne politisk program som et tegn på bevægelsens messianske tendens ${ }^{43}$. Christina Phelps Harris karakteriserede i 1964 Broderskabets anvendelse af et religiøst program, særligt i bevægelsens mest politiske fase ${ }^{44}$, som et forsøg på at "helliggфre deres politiske ekstremisme" ${ }^{45}$. Manfred Halpern gjorde i sit værk fra 1963 gældende, at "neo-islamisk totalitarisme" udnytter traditionen ved at konvertere islam, i krisetider, "into an apocalyptic vision of spiritual and political redemption". Han gjorde dertil gældende, at disse bevægelser "[...] are essentially fascist movements. They concentrate on mobilizing passion and violence to enlarge the power of their charismatic leader and the solidarity of the movement" ${ }^{\prime 4}$. Halpern tilføjede endvidere, at Hasan al-Banna frem til sin død i 1949 personificerede de principielle elementer, som formgav "neoislamiske totalitcere bevagelser" ${ }^{\prime 4}$. Broderskabet italesatte, som han anså det, en ideologi, der var baseret på en øjeblikkelig accept af den fjerne fortid og den fjerne fremtid, men ikke af samtiden. Denne form for ideologi appellerer ifølge Halpern til "befolkningsoverskuddet"48. Han tydeliggjorde, at befolkningsoverskuddet, som Broderskabet evnede at appellere til, var bønder uden jord, arbejdere som var udsatte for arbejdsløshed, studerende uden jobs, religiøst lærde og religiøse embedsfolk, hvis status og muligheder var udsatte pga. sekulariseringen ${ }^{49}$. Idéerne, som blev italesat af Det Muslimske Broderskab, afveg ifølge Halpern fra det traditionelle islam. Han påpegede, at neo-islamiske totalitære bevægelser udelukkende overtog de aspekter fra den islamiske tradition, der tjente bevægelsernes formål ${ }^{50}$. Han tilføjede, at Broderskabets kontakt med den moderne verden gjorde det nødvendigt for bevægelsen at etablere et program. Dette program bestod ifølge Halpern af " a program of repression and death for the insider, aggression and death for the outsider" $"$.

\footnotetext{
${ }^{42}$ Safran, Nadav, 1961, side 231.

${ }^{43}$ Safran, Nadav, 1961, side 239-242.

${ }^{44}$ Det Muslimske Broderskab intensiverede deres politiske ageren i løbet af slut 1930erne og gennem 1940erne. Inden denne periode havde bevægelsen ikke indgået i de politiske processer i Egypten.

${ }^{45}$ P. Harris, Christina, 1964, side 150.

${ }^{46}$ Halpern, Manfred, 1963, side 136.

${ }^{47}$ Halpern, 1963, side 137.

${ }^{48}$ Ibid., side 138.

${ }^{49}$ Ibid., side 138 .

${ }^{50}$ Ibid., side 146.

${ }^{51}$ Ibid., side 143 .
} 
Nyere forskere har ligeledes karakteriseret Det Muslimske Broderskabs politisk-islamiske doktrin som et innovativt koncept. Islamforskeren Jeffrey T. Kenney gjorde gældende, at de islamistiske såvel som sekulære nationalistiske bevægelser i Egypten "blandede politiske og religiøse former og indhold, i deres straben efter at forene befolkningen i en kollektivistisk indsats for at skabe et ideelt samfund, som behandlede nationens materielle og kulturelle behov" ${ }^{2}$. De vestlige forskere Ana Belén Soage og Jorge Fuentelsaz Franganillo opfattede Hasan al-Bannas "islams komplethed (šumuliyyat al-Islam/nizam šamil)" som et koncept, der var inspireret af de totalitære ideologier kendt fra Tysklands og Italiens ledere i begyndelsen af det 20. århunderede ${ }^{53}$.

Nedenstående afsnit vil diskutere divergensen, som forekommer mellem den vestlige forskning og de islamistiske bevægelsers egen fremstilling af deres diskurser. Artiklen vil gennem den historiske kontekst kort tydeliggøre forholdet mellem islam og politik i den islamiske verden.

\section{Innovation kontra tradition}

Ovenstående fremstillinger demonstrerer en klar divergens mellem Det Muslimske Broderskabs selvopfattelse og de vestlige forskeres anskuelse af forholdet mellem islam og politik. Der figurerer især i dele af den vestlige forskning en tendens til at anskue religiøse aktører og idéer som grundlæggende konservative. Forestillingen af religionen som konservativ har rødder i sekulariseringstesen, som i vid udstrækning har domineret den vestlige forskning ${ }^{54}$. De vestlige forskere, der igennem 1950'erne, 60'erne og en del af 70'erne studerede Det Muslimske Broderskab, var inspirerede af modernitetsteorien. Mange indflydelsesrige forskere vurderede qua modernitetsteorien, at religion, som udgjorde et centralt karaktertræk hos Det Muslimske Broderskab, ville eroderes, og derved ville Broderskabet miste sit eksistensgrundlag i samfundet ${ }^{55}$. Disse forskere vurderede, at et moderne samfund behøvede en moderne og derved sekulær ideologi i modsætning til fx Broderskabets islamisk baserede ideologi. Dette kommer blandt andet til udtryk i Halperns anskuelse af Det Muslimske Broderskabs ideologi som en ideologi, der var baseret på øjeblikkelig accept af den fjerne fortid og den fjerne fremtid, men ikke af samtiden. Denne form for ideologi appellerer ifølge Halpern til befolkningsoverskuddet ${ }^{56}$. Halperns udtalelse tydeliggør hans opfattelse af religionen som uløseligt knyttet til anti-modernitet. Det

\footnotetext{
${ }^{52}$ T. Kenney, Jeffrey, 2012, side 427.

${ }^{53}$ Belén Soage, Ana \& Fuentelsaz Franganillo, Jorge, 2010, side 39-40.

${ }^{54}$ Smith, Christian, 1996, side 2.

${ }^{55}$ Smith, Cristian, 1996, side 2.

${ }^{56}$ Halpern, side 138 .
} 
kan imidlertid formodes, at denne antagelse er repræsentativ for dele af den vestlige forskning i sidste halvdel af den 20.århundrede, som i vid udstrækning delte Halperns opfattelse af religion. Forskernes sekulære begrebsverden har således resulteret i den ovennævnte sekulære forståelse af islam. Det vil altså sige, at den sekulære tendens hos de vestlige forskere et langt stykke hen ad vejen har præget deres forståelse af islam som en religiøs doktrin, der altid har været adskilt fra den verdslige sfære. Edward W. Said gør i denne forbindelse gældende, at "orientalisterne" førte "Østen" ind i den moderne tidsalder, hvor verdslighed udgjorde et centralt kendetegn ${ }^{57}$. Ovenstående afsnit har påvist, at flere vestlige forskeres forståelse af islams komplethed har været præget af forskernes sekulære begrebsverden. Nedenstående afsnit vil diskutere dette koncepts ophav og undersøge, hvorvidt konceptet kan spores til islams tidlige historie. Afsnittet vil dertil omfatte en kritisk diskussion af Hasan alBannas opfattelse af šumuliyyat al-Islam, og hvilke koncepter der blev indarbejdet $\mathrm{i}$ denne islamiske ideologi.

\section{Islams Komplethed ud fra en historisk kontekst}

Den herskende forestilling, blandt flere vestlige forskere, om, at islam udgør et koncept adskilt fra de sociale, kulturelle og politiske sfærer i samfundet stemmer helt ikke overens med islams historiske udvikling. Siden det 17. århundrede har der eksisteret en lang proces af vestlig indblanding i de islamiske områder, som igennem det 18. og især det 19.århundrede kom til udtryk ved den vestlige kolonisering af de islamiske områder ${ }^{58}$. Et vigtigt resultat af den vestlige intervention $i$ regionen gjorde sig gældende gennem etableringen af en vestlig sekulær diskurs i regionen. Ifølge forskeren Wael B. Hallaq blev der af de vestlige magter udarbejdet en væsentlig strategi som havde til formål at "erobre sindene" for derved at diskreditere den islamiske lovs position i samfundene i forsøget på at erstatte den med kodificeret $\operatorname{lov}^{59}$. Derved kan det siges, at der eksisterer en klar sammenhæng mellem den vestlige kolonisering af regionen og privatiseringen af islam ${ }^{60}$. Hasan al-Banna bestred gennem sine breve og taler den vestlige og til tider arabisk/islamiske ${ }^{61}$ fremstilling af islam som et koncept adskilt fra det verdslige. Han understregede blandt andet i det åbne brev

\footnotetext{
${ }^{57}$ W. Said, Edward, 2015, side 152.

${ }^{58}$ J. Donohue, John \& L. Esposito, John, 2007, side 3.

${ }^{59}$ B. Hallaq, Wael, 2009, side 435.

${ }^{60}$ Med privatiseringen af islam menes at religionen med tiden er blevet fremstillet som et koncept, der udelukkende omhandler den private sfære uden at tage stilling til politiske og sociale udviklinger.

${ }^{61}$ Nogle af de sekulærorienterede forfattere i den arabiske verden adopterede ligeledes denne forestilling.
} 
" Bayn al-ams wa-l yawm ( Mellem i går og i dag)", at " islams modstandere har formået at narre de intellektuelle muslimer og at afskærme andres syn, ved at fremstille islam som værende begrænset til dogmer, tilbedelse og moral samt forskellige overtroiske ritualer[...] Dette har nu stået på så længe, at det er blevet en svær opgave at forklare, at islam udgør et omfattende socialt system, som varetager alle livets anliggender" 62 .

Hasan al-Banna understregede endvidere, at det Muslimske Broderskab ikke er begrænset til at være velfærdsorganisation eller et politisk parti, imidlertid er den en bevægelse, der forkynder

"... det islam som blev bibragt af profeten Muhammad, og her udgør regeringen en central del[...]"63.

Al-Banna argumenterede således for, at Broderskabets opgave bestod af at etablere en islamisk stat ${ }^{64}$.

Den socialpolitiske forståelse af islam, som Hasan al-Banna gav udtryk for, stemmer et langt stykke hen ad vejen overens med den traditionelle islamiske skildring. Den islamiske tradition blev igennem det meste af historien ikke opfattet som en passiv idé. Der eksisterede derimod en holistisk opfattelse af islam, hvor religion var nøje affilieret med politik såvel som lov. Muslimerne har gennem historien argumenteret for, at den socialpolitiske forståelse af islam stammede fra de normative tekster (Koranen og Sunnah) ${ }^{65}$. Ahmad Ibn Taymiyya (d. 1328) argumenterede i det 14.århundrede imod adskillelsen mellem politisk magt (siyasa) og lov ( ̌sari'a). Han gjorde i den forbindelse gældende, at adskillelsen mellem disse domæner ville skade herskeren såvel som folket "If the Sultan is isolated from the religion or the religion from the sultan, then the state of the people is corrupted[...]"66.

Ifølge Ibn Taymiyya var det nødvendigt at etablere et samarbejde (ta'awun) mellem herskeren og de lærde. Ibn al-Qayyim al-Jawziyya (d. 1350), Ibn Taymiyyas elev, forklarede, at Ibn Taymiyya var fortaler for en genforening af de ovenstående domæner, så de kunne stemme overens med eksemplet fra de tidligste muslimer ${ }^{67}$.

Den historiske kontekst demonstrerer ligeledes, at det muslimske samfund efter profetens migration til Yathrib, en by beliggende omkring $480 \mathrm{~km}$ nordøst for Mekka i 622, udviklede sig til et politisk såvel som religiøst organiseret samfund. I denne forbindelse fik

\footnotetext{
${ }^{62}$ Al-Banna, 2004, side 105-106-

${ }^{63}$ Al-Banna, 2004, side 110.

${ }^{64}$ Al-Banna, 2004, side 106

${ }^{65}$ J. Donohue, John \& L. Esposito, John, 2007, side 3.

${ }^{66}$ E. Vogel,Frank, 2000, side 202.

${ }^{67}$ E. Vogel,Frank, 2000, side 204.
} 
profeten Muhammad rollen som politisk og militærleder ${ }^{68}$. Derved fremgår det, at islam meget tidligt efter dens opståen i det 7.århundrede repræsenterede og blev opfattet som en holistisk tradition.

Det fremgår altså, at den islamiske verden frem til frembruddet af de moderne nationalstater i 1800-tallet var karakteriseret af en klar sammenhæng mellem religion og politik. Til trods for den til tider tekniske adskillelse mellem de religiøse og politiske institutioner, så eksisterede der til stadighed en klar forståelse af islam som den legitimerende faktor for statsoverhovedet. Denne virkelighed blev dog radikalt ændret $\mathrm{i}$ takt med, at de moderne nationalstater tog form $\mathrm{i}$ regionen. I forbindelse med den stigende vestlige tilstedeværelse i regionen i form af militær besættelse samt spredningen af vestlige, sekulære idéer opstod en moderne islamisk reaktion. Det var i denne forbindelse, at Det Muslimske Broderskab udarbejdede, det de kaldte en islamisk mission (da'wa) som skulle modarbejde vanskelighederne og udfordringerne frembragt af den moderne stat. Modsat de ovennævnte vestlige fortolkninger af denne ideologi, som en udelukkende innovativ og traditionsløs ideologi, hævder denne artikel, at Broderskabets ideologi byggede på en velkendt islamisk diskurs, som dog blev kombineret med moderne begreber. Det er i den anledning signifikant at undersøge, hvordan Hasan al-Banna og Det Muslimske Broderskab kombinerede den førnævnte islamiske diskurs med moderne begreber, for derved at kunne anvende denne diskurs $\mathrm{i}$ den moderne kontekst, som prægede det egyptiske samfund.

Hasan al-Banna var af den anskuelse, at muslimernes svaghed $\mathrm{i}$ høj grad beroede på deres afvigelse fra den "sande islam". Han anslog $\mathrm{i}$ den forbindelse, at muslimerne skulle forstå og eksekvere islam i overensstemmelse de normative tekster i islam (Koran og Hadith) samt efterleve eksemplerne fra de tidlige muslimske generationer "alsalaf" for at kunne udarbejde en korrekt islamisk reform ${ }^{69}$. Al-Banna gjorde endvidere gældende, at løsningen på Egyptens socioøkonomiske og kulturelle problemer afhang af at virkeliggøre islam som et altomfattende system, der definerede alle livets aspekter. Hasan al-Banna forklarede, at en tilbagevenden til det islamiske system (al-nizam al-islami), hvori islam dannede grundlag for religion og stat (din wa dawla), ville beskytte Egypten mod de sociale trusler og genetablere roen i samfundet. Dette islamiske system var ifølge alBanna ikke et innovativt system, men et velkendt og traditionelt system, som havde eksisteret siden det syvende århundrede ${ }^{70}$. Vigtigst af Hasan al-Bannas idéer var forestillingen om, at loven i de islamiske samfund skulle være i overensstemmelse med de normative tekster i Islam. Han baserede denne anskuelse på forskellige koranvers, som ekspliciterede forpligtelsen til at herske og lovgive i henhold til Guds

\footnotetext{
${ }^{68}$ Mansfield, Peter, 1992, side 23.

${ }^{69} \mathrm{Al}$-Banna, 2004, side 120.

${ }^{70}$ Al-Banna, 2004, side 302-303.
} 
åbenbarede love, og han citerede fx koranverset; "... And whoever does not judge by what Allah has revealed - then it is those who are the defiantly disobedient." [5:47] $]^{71}$. Denne fortolkning repræsenterede en fortsættelse af en traditionel islamisk opfattelse, som ligeledes blev italesat af store islamiske lærde. Det fremgår blandt andet, at Abu Hanifa $^{72}$ allerede i det 8 . århundrede påpegede, at et islamisk område skulle underlægges islamisk $\operatorname{lov}^{73}$.

Det gør sig imidlertid gældende, at den islamiske diskurs, som Hasan al-Banna udarbejdede, udover at indeholde karakteristika fra en lang islamisk tradition, som kan spores tilbage til profetens tid, også bestod af moderne koncepter som ikke havde rødder i den islamiske overlevering. Al-Bannas forståelse af forholdet mellem politik og islam byggede til en vis grad på traditionelle idéer, som var blevet italesat af lærde som Ibn Taymiyya og Abu Hanifa. Ibn Taymiyya fremførte i sit værk "The Religious Law (Al-Siyasa al-šhar'iyya)" fra 1311-1315, at islamisk lov skulle appliceres i regeringsprocessen ${ }^{74}$. Det var Ibn Taymiyyas hensigt at opnå et " retskaffent styre" ved at skabe en syntese mellem de religiøse og politiske sfærer. Det skal dog fremhæves i denne forbindelse, at Ibn Taymiyya skrev i en kontekst, som differerede stærkt fra den kontekst, Hasan al-Banna var præget af. Ifølge Ibn Taymiyya kunne religionen ikke praktiseres uden en statsmagt. De religiøse pligter, som at påbyde det gode og forbyde det onde (al-amr bel ma'ruf wal-nahi 'an al-munkar), samt udførelsen af krig, etableringen af retfærdighed, pilgrimsfærden, juridiske straffe osv. kunne ifølge Ibn Taymiyya ikke gennemføres "except through the power and authority of a leader (imam)" "75. Det gjordes således gældende af Ibn Taymiyya, at lederskab og šari'a skulle indgå i en tæt syntese, for derved at opnå et retskaffent styre.

Den islamiske verden gennemgik, i forbindelse med det osmanniske kalifats afskaffelse i 1924, en radikal udvikling. Kalifatets fald afstedkom et magt-tomrum, som blandt andet resulterede i grundlæggelsen af en gennemgribende ny virkelighed i regionen. På baggrund af denne udvikling opstod nye nationalstater grundlagt af sekulære politiske eliter. I denne periode italesatte disse arabiske ledere idéer som antiimperialisme, nationalisme og socialisme. I forlængelse af de sekulære eliters overtagelse af magten i fx Syrien, Egypten og Irak, blev islam i stigende grad isoleret fra de politiske sfærer. Hasan al-Banna ønskede gennem Broderskabet at italesætte og sprede budskabet om det islamiske system (al-nizam al-islami) som et modsvar til den sekulære diskurs, som var i højsæde i denne periode ${ }^{76}$. Al-Banna var af den anskuelse, at det islamiske system, som han

\footnotetext{
${ }^{71}$ Al-Banna, 2004, side 139-140.

${ }^{72}$ Abu Hanifa al-Nu'man (d. 767), teolog og jurist, var grundlægger af Hanafi- rets skolen en af de fire rets skoler inden for Sunni-islam.

${ }^{73}$ Michot, Yahya, 2006, side 109.

${ }^{74}$ Black, Antony, 2001, side 155.

${ }^{75}$ Black, 2001, side 155.

${ }^{76}$ Black, 2001, side 319.
} 
propagerede, skulle fremskynde en tilbagevenden til islam som et altomfattende system, hvor de politiske, sociale og økonomiske aspekter skulle udgøre en helhed. Det er imidlertid interessant, at Hasan al-Banna i denne forbindelse, og i et forsøg på at italesætte en ideologi som propageres $i$ en moderne kontekst, inkorporerede forskellige begreber, som fx nationalisme, patriotisme og social reform i sin islamiske diskurs.

Det fremgår bl.a., at flere af de koncepter, som Hasan al-Banna italesatte som islamiske traditioner $\mathrm{i}$ forsøget på at skabe den tilønskede islamiske reform, var inspireret af moderne vestlige koncepter. Wael Hallaq påpeger $\mathrm{i}$ denne forbindelse, at Det Muslimske Broderskab aldrig forklarede, hvilken form for šari’a der skulle appliceres ifølge deres begrebsverden ${ }^{77}$. Denne abstrakthed, som prægede al-Bannas šaria-koncepter, i modsætning til Ibn Taymiyyas konkrete forståelse af samme koncept skyldtes i høj grad den intellektuelle baggrund for de to mænd. Al-Banna var en moderne læreruddannet, uden en traditionel islamisk uddannelse. Han opnåede sin religiøse viden gennem faderens indflydelse samt indflydelsen fra forskellige lokale religiøse mænd ${ }^{78}$. Ibn Taymiyya var derimod uddannet i Hanbali-traditionen og var en anerkendt lærd gennem sin levetid $^{79}$. Al-Bannas mangel på en traditionel islamisk uddannelse kan derved forklare Det Muslimske Broderskabs abstrakte forståelse af šarialov, som Hallaq påpeger i sit værk.

\section{Det islamiske system (al-nizam al-Islami)}

Reformarbejdet og ideologien, som det muslimske broderskab udarbejdede, omfattede sociale, $\varnothing$ konomiske, videnskabelige, politiske og militære aktiviteter, og kendetegnende for disse aktiviteter var, at de alle blev tildelt og italesat gennem islamiske termer og begreber ${ }^{80}$. Hasan al-Banna skrev blandt andet i det åbne brev "Ila al-Šabab (til de unge)", at Broderskabets reformidéer udelukkende var baseret på islams velkendte traditioner ${ }^{81}$. Han tilføjede endvidere, at Broderskabet ikke anerkender andre systemer end det islamiske og heller ikke efterkommer andre love end islams love ${ }^{82}$. Det anskueliggøres af denne udtalelse, at al-Banna italesatte Broderskabets opfattelse af islam som en livsfilosofi frem for et sæt religiøse og spirituelle ritualer.

Et eksempel på Hasan al-Bannas inkorporering af moderne vestlige koncepter til den islamiske diskurs, fremstår af hans italesættelse af

\footnotetext{
${ }^{77}$ Hallaq, 2009, side 478.

${ }^{78}$ Belén, Soage \& Fuentelsaz, Franganillo, 2010,side 39.

${ }^{79}$ Hanbali, er en af de 4 anerkendte rets skoler inden for Sunniislam.

${ }^{80}$ Husaini, Musa, 1956, side 45.

${ }^{81}$ Al-Banna, 2004, side 179.

${ }^{82}$ Al-Banna, 2004, side 175.
} 
nationalisme som et islamisk koncept. Al-Banna var af den anskuelse, at nationalisme repræsenterede en central del af den islamiske doktrin $^{83}$. Indarbejdelsen af nationalisme $i$ Det Muslimske Broderskabs islamiske ideologi skyldtes den politiske kontekst, der prægede det egyptiske samfund i den periode. Egypten var, siden 1919 revolutionen $^{84}$, præget af en stærk nationalistisk ånd, som var fremherskende i størstedelen af det egyptiske samfund. I forlængelse af dette, italesatte Hasan al-Banna en syntese mellem islam og en nationalistisk diskurs, $\mathrm{i}$ forsøget på at appellere til de islamiske såvel som nationalistiske følelser i samfundet. Italesættelsen af nationalisme som en traditionel del af islam, repræsenterede imidlertid en innovation som fx stod i klar kontrast til Ibn Taymiyyas opfattelse af Islam.

Det fremgår dertil, at Hasan al-Banna fremsatte Broderskabets reformsystem som et traditionelt islamisk system ${ }^{85}$. Al-Banna udarbejdede forskellige sociale aktiviteter, som gjorde bevægelsen i stand til at mobilisere græsrødderne i det egyptiske samfund. Reformidéerne som bevægelsen italesatte besad uden tvivl islamiske træk, som fx tarbiyya-konceptet ${ }^{86}$ samt udbredelsen af islamiske principper i samfundet. Det fremstår dog ligeledes, at de sociale aktiviteter, som bevægelsen udarbejdede i denne periode, bar præg af national socialisme i deres indhold såvel som fremgangsmåde ${ }^{87}$.

Denne affinitet mellem vestlige og islamiske idéer illustrerer, at Hasan al-Bannas islamiske diskurs overordnet repræsenterede en fortsættelse af Ibn Taymiyyas islamiske begrebsverden, men samtidig indbefattede diskursen klare brud med den traditionelle islamiske ideologi. Det kan dertil anføres, at Hasan al-Banna anvendte moderne metoder til at propagere sin ideologi i det egyptiske samfund. Baron Beth gør blandt andet gældende, at Broderskabet i forbindelse med propagandaaktiviteterne adopterede flere af de metoder, som blev anvendt af kristne missionærer i Egypten. Beth anfører, at "The Brotherhood consciously learned from them and adapted their tools to fight them, in the process transforming these tools and techniques" $" 88$. Det skal derved påpeges, at bevægelsen udover at italesætte en syntese mellem en islamisk og moderne ideologi, også udarbejdede en moderne organisatorisk struktur, som ikke havde eksisteret i de tidligere islamiske bevægelser. Hasan al-Banna udarbejdede i modsætning til tidligere reformister som Abduh og Rida, en social bevægelse som ikke var kendt fra den islamiske historie, men som

\footnotetext{
${ }^{83}$ Al-Banna, 2004, side 19.

${ }^{84}$ I 1919 udbrød en folkelig nationalistisk revolution i Egypten, som gjorde krav på egyptisk selvstændighed.

${ }^{85}$ Al-Banna, 2004, side 152.

${ }^{86}$ Tarbiyya betyder uddannelse. Det Muslimske Broderskab udarbejdede et system for uddannelsen af deres medlemmer i religiøse videnskaber og traditioner.

${ }^{87}$ Husaini, Musa, side 57.

${ }^{88}$ Beth, Baron, 2014, side 134.
} 
skaffede bevægelsen en stærk mobiliseringsevne på den egyptiske scene i den moderne kontekst.

\section{Konklusion}

Hasan al-Banna udarbejdede, som reaktion på den stigende vestlige dominans i Egypten, en ideologi, der blev italesat som en del af den traditionelle islamiske opfattelse. Ifølge Hasan al-Bannas begrebsverden, kunne behovet for socioøkonomisk og politisk reform i samfundene kun imødekommes, såfremt disse samfund vendte tilbage til det " oprindelige islam". I forlængelse af dette, grundlagde Hasan al-Banna en "islamisk" bevægelse, som i løbet af perioden 1928-1941, evnede at opbygge en bred folkelig base i Egypten.

Flere vestlige forskere har diskuteret indholdet af Broderskabets ideologi, i forsøget på at nå til en forståelse af bevægelsens mobiliseringsevne i samfundet. Nogle forskere gjorde gældende, at denne ideologi byggede på innovative idéer, som et langt stykke hen ad vejen afveg fra det traditionelle islam. Andre forskere anslog, at denne anskuelse var forkert, idet politisk islam kan spores tilbage til profetens tid.

Det fremgår imidlertid, at Hasan al-Banna udarbejdede en moderne ideologi, som byggede på en traditionel opfattelse af islam, som et politisk, socialt og religiøst system. Det kan siges, at denne traditionelle opfattelse dannede ramme for en moderne ideologi, som var inspireret af islamiske såvel som moderne vestlige koncepter. Denne affinitet, mellem det traditionelle og det moderne, må siges at have været en pragmatisk løsning, som dog afstedkom, at Det Muslimske Broderskab, i en periode præget af krise og intellektuelle brud, evnede at mobilisere blandt flere sociale og politiske lag i det egyptiske samfund.

\section{Forfatterpræsentation}

Ahmed Abou el-Zalaf har opnået Kandidatgraden i historie fra Københavns Universitet. El-Zalaf har, gennem sine studier, arbejdet tæt og dybt med flere aspekter af udviklingen i Mellemøstens moderne historie. Han har arbejdet tæt med udviklingen af den politisk-islamiske ideologi, og studeret hvordan denne ideologi har præget samfundene i førnævnte region. El-Zalaf skrev speciale om Det Muslimske Broderskabs mobilisering i perioden 1928-41. Specialet fokuserede i høj grad på, hvilken betydning ideologien havde for Broderskabets mobilisering og appel i samfundet. 


\section{Litteraturliste}

Abd al-Halim, Mahmoud, 1994: "Ahdath Sana'at al-Tarikh (Begivenheder som skabte historien)" Kairo.

Al-Anani, Khalil, 2013: " The Power of the Jama 'A: The Role of Hasan Al-Banna in Constructing the Muslim Brotherhood's Collective Identity" fra "Sociology of Islam. S, 41-63.

Al-Banna, Hasan, 2004: " Majmu'at rasa'il al-Imam al-šahid Hasa al-Banna( Samlingen af Hasan al-Bannas breve)" Beirut.

Al-Banna, Hasan, 2013 "Mudhakira al-Da'wa wal-

Da 'iya(Erindringer for missionen og missionceren)", Kairo.

Al-Bayyumi Ghanem, Ibrahim, 2013: "Al-Fikr al-Siyasi, Lil Imam Hasan al-Banna; (Den politiske ideologi hos imamen Hasan alBanna)", Madarat, Kairo.

B. Hallaq, Wael, 2009: "Sharia, Theory, Practice, Transformation" Cambridge University Press,.

Baron, Beth, 2014: " The Orphan Scandal, Christian Missionaries and the Rise of The Muslim Brotherhood", Stanford University Press.

Belén Soage, Ana \& Franganillo, J.F, 2010: "The Muslim Brothers In Egypt". I Rubin, Barry (red.) " The Muslim Brotherhood, The Organization and Policies of a Global Islamist Movement" Palgrave Macmillan. S, 39-57.

Black, Antony, 2001: "The History of Islamic Political Thought, From the Prophet to the Present” Routledge.

E. Vogel, Frank, 2000: "Islamic Law and Legal System, Studies of Saudi Arabia" BRILL.

Geroshni, Israel \& P. Jankowski, James, 2002: " Redefining the Egyptian Nation 1930-1945", Cambridge University Press.

Guirguis, Max, 2012: "Islamic Resurgence and Its Consequences in the Egyptian Experience" Mediterranean Studies, Volume 20, Number 2.

Haddad, Yvonne 2008: "Muhammad Abduh: Pioneer of Islamic Reform" i Rahnema, Ali (red.) "Pioneers of Islamic Revival" World Book Publishing. S 30-64. 
Halpern, Manfred, 1963: "The Politics of Social Change In the Middle East and North Africa", Princeton University Press.

Hawwa, Sa'id, 1984: "Al-madkhal ila Da'wat al-ikhwan almuslimiin( Indgangen til Det Muslimske Broderskabs Mission)"Kairo.

Helbawy, Kamal, 2010: "The Muslim Brotherhood In Egypt, Historical evolution and future prospects". I Hroub, Khaled "Political Islam, Context versus Ideology", London Middle East Institute at SOAS. S, 61-86.

J. Donohue, John \& L. Esposito, John, 1992: " Islam in Transition, Muslim Perspectives" Oxford University press.

Mansfield, Peter, 1992: "The Arabs" Penguin Books.

Michot, Yahya, 2006: "Muslims Under Non-muslim Rule, Ibn Taymiyya" Interface Publications.

Musa Husaini, Ishak, 1956: "The Muslim Brethren, The Greatest of Modern Islamic Movements", Khayat College Book Cooperative, Beirut.

P. Harris, Christina, 1964: "Nationalism and Revolution in Egypt, The Role of the Muslim Brotherhood", The Hoover Institution.

R. Keddie, Nikki, 2008: "Sayyid Jamal al-Din 'al-Afghani"”. I Rahnema Ali (red.)" Pioneers of Islamic Revival" World Book Publishing. S, 11-30.

Rahmena, Ali, 2008: "Introduction to 2nd Edition: Contextualizing the Pioneers of Islamic Rivival". I Rahnema Ali (red.)" Pioneers of Islamic Revival" World Book Publishing. S, ix-1.

Safran, Nadav, 1961: "Egypt in search of politcal community, an analysis of the Intellectual and political evolution of Egypt, 18041952" Havard University Press.

Smith, Christian, 1996: "Disruptive Religion, the Force of Faith in Social Movement Activism" Routledge.

T. Kenney, Jeffrey, 2012: "Millennial Politics in Modern Egypt: Islamism And Secular Nationalism in Context and Contest", Department of Religious Studies, DePauw University.

W. Said, Edward, 2015: “Orientalisme, Vestlige forestillinger om Orienten" Roskildeuniversitetsforlag. 